\title{
Improvement in Nutritional Status of Protein-Malnutrition Elderly after Intervention Using a Casein-Based Balanced Liquid Nutrition Formula as Nutritional Support
}

\author{
Kenji Mizumoto1, Xudong Xiong², Hua Yan², Xiaolin Wang3 ${ }^{3}$, Zaisi Ji ${ }^{1,2,3 *}$, \\ Hajime Sasaki ${ }^{1,4 *}$ \\ ${ }^{1}$ Food Science Research Laboratories, Meiji Co. Ltd., Odawara, Japan \\ ${ }^{2}$ Shuguang Hospital Affiliated to Shanghai University of Traditional Chinese Medicine, Shanghai, China \\ ${ }^{3}$ Shanghai Meiji Health Science and Technology, Inc., Shanghai, China \\ ${ }^{4}$ Department of Nutritional and Life Science, Kanagawa Institute of Technology, Atsugi, Japan \\ Email: ${ }^{*}$ zai-si.ji@meiji.com, ${ }^{*}$ sasaki@bio.kanagawa-it.ac.jp
}

Received 3 October 2013; revised 22 February 2014; accepted 1 March 2014

Copyright (C) 2014 by authors and Scientific Research Publishing Inc.

This work is licensed under the Creative Commons Attribution International License (CC BY).

http://creativecommons.org/licenses/by/4.0/

c) (i) Open Access

\section{Abstract}

A nutritional intervention for 8 weeks was conducted in the elderly ( $>65$ y) living in nursing homes in Shanghai, who showed body weight within the normal range but albumin levels of $<35$ $\mathrm{g} / \mathrm{L}$. The intervened took $400 \mathrm{kcal} /$ day of a balanced liquid nutrition formula containing casein as a major protein source $(90 \%$ of total protein) in addition to their daily diets, while the non-intervened took only daily diets. Daily diet intakes during the trial were $1738 \pm 240 \mathrm{kcal} / \mathrm{day}$ in the intervened and $1612 \pm 187 \mathrm{kcal} /$ day in the non-intervened. The energy intake in the intervened was compensated for by reducing their daily diets, which resulted in a similar level to that in the non-intervened. This intervention resulted in intakes of protein and carbohydrate being significantly increased: P16.4\%, F27.3\%, C56.3\% in the intervened; P13.0\%, F36.3\%, C50.7\% in the non-intervened. Albumin level of the intervened increased from $32.7 \pm 3.1 \mathrm{~g} / \mathrm{L}$ to $37.3 \pm 1.9 \mathrm{~g} / \mathrm{L}$, while it did not significantly change in the non-intervened: $30.0 \pm 4.2 \mathrm{~g} / \mathrm{L}$ to $31.3 \pm 4.6 \mathrm{~g} / \mathrm{L}$. Using GNRI (geriatric nutritional risk index), nutritional risk levels were assessed; GNRI of the intervened significantly improved from $88.7 \pm 6.3$ (intermediate risk) to $95.7 \pm 4.5$ (low risk), while its status did not change in the non-intervened: $84.6 \pm 7.7$ (intermediate risk) to $86.5 \pm 7.9$ (intermediate risk). The intervention using a casein-based balanced liquid nutrition formula effectively improved pro-

*Corresponding author.

How to cite this paper: Mizumoto, K., et al. (2014) Improvement in Nutritional Status of Protein-Malnutrition Elderly after Intervention Using a Casein-Based Balanced Liquid Nutrition Formula as Nutritional Support. Food and Nutrition Sciences, 5, 1083-1093. http://dx.doi.org/10.4236/fns.2014.511118 
tein-malnutrition in the elderly. This result suggests that a casein-based balanced liquid nutrition formula is an effective nutrition source that can be applied to a nutritional program to improve malnutrition of the elderly.

\author{
Keywords
}

Elderly, Protein, Casein, Energy, Malnutrition, Liquid Nutrition Formula

\title{
1. Introduction
}

It is often noted that dietary intakes of the elderly do not provide necessary amounts of energy and protein. If a lack of energy and protein intake persists, it can lead to protein-energy malnutrition (PEM). PEM is a cause of a variety of health-related problems such as impaired daily life activity, decreased cure rate, increased incidence of complications, and prolonged hospitalization period [1]-[4]. PEM also deteriorates immune function of the elderly, which results in increased incidence of infectious diseases that affect life expectancy [5].

The prevalence of PEM in Japan is reported to be $40 \%$ among the hospitalized elderly and $30 \%$ among the home-care elderly [6]. In Europe, it is reported that the prevalence of PEM ranges from 20\% to 50\% [7]-[9]. It should be recognized that PEM is the major concern regarding nutritional problems of the elderly in many countries. To avoid PEM and PEM-related problems in the elderly, it is necessary to prevent aggravation of an early stage of malnutrition that leads to PEM [10]-[12].

PEM is defined by decreases in both serum albumin and body weight [13] [14]. For example, PEM classified as "low grade" is associated with albumin levels of 31 to $34 \mathrm{~g} / \mathrm{L}$ and body weight levels of $85 \%$ to $90 \%$ of the ideal body weight. If no serious complications are involved, low levels of albumin without a decrease in body weight define this type of nutritional status as hypoalbuminemia or protein-malnutrition, which is caused by lowered dietary protein intakes [15]. If protein-malnutrition persists, it causes a loss of body weight, and subsequently deteriorates into PEM. Therefore, protein-malnutrition should be recognized as a preliminary step towards PEM, and it should be ameliorated by improving nutritional intake.

In this report, we describe a nutritional intervention trial performed in nursing homes for the elderly in Shanghai. The subjects' body weights were within the normal range, but their albumin levels were below $35 \mathrm{~g} / \mathrm{L}$, which revealed that they were suffering from protein-malnutrition. We conducted nutritional intervention for 8 weeks by using a balanced liquid nutrition formula as a nutritional support, whose major protein source is casein ( $90 \%$ of total protein). The results show that the intervention effectively improved protein-malnutrition. Along with the improvement of protein-malnutrition, nutritional risk levels were also improved.

\section{Experimental Methods}

\subsection{Ethical Statement}

This study was conducted according to the guidelines laid down in the Declaration of Helsinki and all procedures involving human subjects were approved by the Human Ethics Committee of Shuguang Hospital, Shanghai University of Traditional Chinese Medicine.

\subsection{Subjects}

The elderly over 65 year old living in nursing homes adjunct to Shuguang Hospital, Shanghai University of Traditional Chinese Medicine and Shanghai No 3 Social Welfare Institution were enrolled. The participants were selected from among the elderly living without daily living aids based on their albumin levels $(<35 \mathrm{~g} / \mathrm{L})$ and health conditions. The number of participants and their age distribution are shown in Table 1.

\subsection{Balanced Liquid Nutrition Formula}

Meibalance HP 1.0 (200 kcal/200 ml/package, Meiji Co. Ltd., Tokyo, Japan) was used as a balanced liquid nutrition formula. Its nutritional data are shown in Table 2. The protein in this balanced nutrition formula was con- 
Table 1. Gender ratio and age distribution.

\begin{tabular}{cccc}
\hline & Intervened & Non-intervened & \\
Number & 15 & 15 & \\
Male:Female & $7: 8$ & $6: 9$ & NS \\
Age & $70.1 \pm 3.3$ & $71.5 \pm 2.5$ & \\
\hline
\end{tabular}

Data are shown as average \pm standard deviation. NS: Not statistically significant.

Table 2. Nutritional components (per $100 \mathrm{ml}$ ).

\begin{tabular}{|c|c|c|}
\hline Energy & kcal & 100 \\
\hline Protein & g & 5.0 \\
\hline (Casein) & & $(4.5)$ \\
\hline (Whey protein) & & $(0.5)$ \\
\hline Lipid & g & 2.5 \\
\hline Carbohydrate & g & 14.1 \\
\hline Fiber & g & 1.2 \\
\hline Vitamin A & $\mu \mathrm{g} \mathrm{RE}{ }^{*}$ & 60 \\
\hline Vitamin D & $\mu \mathrm{g}$ & 0.5 \\
\hline Vitamin E & $\mathrm{mg}$ & 3.0 \\
\hline Vitamin K & $\mu \mathrm{g}$ & 5.0 \\
\hline Vitamin B1 & $\mathrm{mg}$ & 0.15 \\
\hline Vitamin B2 & $\mathrm{mg}$ & 0.20 \\
\hline Niacin & mg NE ${ }^{*}$ & 2.8 \\
\hline Vitamin B6 & $\mathrm{mg}$ & 0.30 \\
\hline Folic acid & $\mu \mathrm{g}$ & 50 \\
\hline Vitamin B12 & $\mu \mathrm{g}$ & 0.60 \\
\hline Biotin & $\mu \mathrm{g}$ & 15.0 \\
\hline Pantotenic acid & $\mathrm{mg}$ & 0.60 \\
\hline Vitamin C & mg & 16 \\
\hline Choline & $\mathrm{mg}$ & 1.8 \\
\hline $\mathrm{Na}$ & $\mathrm{mg}$ & 110 \\
\hline $\mathrm{K}$ & mg & 100 \\
\hline $\mathrm{Cl}$ & $\mathrm{mg}$ & 110 \\
\hline $\mathrm{P}$ & $\mathrm{mg}$ & 70 \\
\hline $\mathrm{Ca}$ & $\mathrm{mg}$ & 70 \\
\hline $\mathrm{Mg}$ & $\mathrm{mg}$ & 30 \\
\hline I & $\mu g$ & 15 \\
\hline $\mathrm{Fe}$ & $\mathrm{mg}$ & 1.0 \\
\hline $\mathrm{Mn}$ & $\mathrm{mg}$ & 0.23 \\
\hline $\mathrm{Cu}$ & $\mathrm{mg}$ & 0.050 \\
\hline $\mathrm{Zn}$ & $\mathrm{mg}$ & 1.0 \\
\hline Se & $\mu \mathrm{g}$ & 6 \\
\hline $\mathrm{Cr}$ & $\mu \mathrm{g}$ & 3.0 \\
\hline Mo & $\mu \mathrm{g}$ & 2.5 \\
\hline
\end{tabular}

*RE, retinol equivalent; $\mathrm{NE}$, niacin equivalent. 
trolled so as to consist of $90 \%$ cow milk casein and $10 \%$ cow milk whey proteins, cf. the ratio of casein (80\%) and whey proteins $(20 \%)$ in cow milk.

\subsection{Intervention}

The intervened took 2 packages of Meibalance ( $400 \mathrm{kcal}$ ) in a day in addition to their daily diets (breakfast, lunch, dinner, and snacks): $200 \mathrm{kcal}$ before or after lunch and $200 \mathrm{kcal}$ before bedtime. Nutritional instructions were applied to the intervened to reduce their daily diets by $400 \mathrm{kcal}$. The non-intervened group took only their daily diets (breakfast, lunch, dinner, and snacks). The intervention period lasted 8 weeks.

\subsection{Meal Survey}

Physical measurements and blood biochemical measurements were performed at 0,4 , and 8 weeks in the intervened, while they were performed at 0 and 8 weeks in the non-intervened. Blood collection was performed at 8 a.m. before breakfast. Collected blood was applied to analyses at the hospitals with which the participants were associated.

\subsection{Measurements}

Physical measurements and blood biochemical measurements were performed at 0,4 , and 8 weeks in the intervened, while they were performed at 0 and 8 weeks in the non-intervened. Blood collection was performed at 8 a.m. before breakfast. Collected blood was applied to analyses at the hospitals with which the participants were associated.

\subsection{Nutritional Risk Assessment}

Nutritional risks were assessed with GNRI (geriatric nutritional risk index) [16] using the following equation. GNRI $=1.489 \times$ albumin $(\mathrm{g} / \mathrm{L})+41.7 \times$ body weight/ideal body weight Ideal body weight was calculated using Lorentz equations [16].

Male: height -100 - (height -150$) / 4$

Female: height -100 - (height -150$) / 2.5$

When the body weight/ideal body weight ratio was $>1$, body weight/ideal body weight $=1$ was used as described in the original report [16].

GNRI risk levels are classified as follows: high risk, $<82$; intermediate risk, 82 to $<92$; low risk, 92 to $\leq 98$; no risk, $>98[16]$.

\subsection{Statistical Analysis}

Statistical analysis was performed using IBM SPSS Statistics 20 (IBM, Tokyo, Japan). The difference between two paired samples was tested by the paired $t$ test. The difference between two independent samples was tested by the standard t test. The Bonferroni method for multiple comparisons was used to examine the difference in the time courses of albumin levels and GNRI.

\section{Results}

\subsection{Nutritional Intake}

Energy intakes in the intervened and non-intervened were $1738 \pm 240 \mathrm{kcal}$ and $1612 \pm 187 \mathrm{kcal}$, respectively. There was no significant difference between them (Table 3). Intakes of the three major nutrients in the intervened were as shown in Table 3. Protein and carbohydrate intakes were significantly higher in the intervened than in the non-intervened.

\subsection{Nutritional Assessment}

Markers measured for nutritional assessments are shown in Table 4. Differences of the measured figures between 0 and 8 weeks are shown in Table 5 . 
Table 3. Calorie intakes.

\begin{tabular}{cccc}
\hline & \multicolumn{3}{c}{ Calorie intake (kcal) } \\
\cline { 2 - 3 } & Intervened & Non-intervened & p \\
\hline Total & $1738 \pm 240$ & $1612 \pm 187$ \\
Protein & $285 \pm 62$ & $210 \pm 47$ & $*$ \\
Fat & $475 \pm 160$ & $585 \pm 232$ & $*$ ** \\
Carbohydrate & $978 \pm 18$ & $817 \pm 71$ \\
\hline & & Calorie ratio (\%) & \\
& Intervened & Non-intervened & \\
Protein & 16.4 & 13.0 \\
Fat & 27.3 & 36.3 \\
Carbohydrate & 56.3 & 50.7 \\
\hline
\end{tabular}

Data are shown as average \pm standard deviation. Statistical significance is shown by asterisks: ${ }^{*} \mathrm{p}<0.05 ;{ }^{* *} \mathrm{p}<0.01$.

\subsubsection{Physical Measurement}

By the intervention, body weight, BMI, arm circumference and arm muscle circumference increased (Table 4 and Table 5). In the non-intervened, there were no such increases.

\subsubsection{Blood Biochemical Analysis}

In the intervened, albumin levels significantly increased; at the start of intervention, albumin level was below normal $(32.7 \pm 3.1 \mathrm{~g} / \mathrm{L})$, and at the end it was within the normal range (37.3 $\pm 1.9 \mathrm{~g} / \mathrm{L})$ (Table 4 and Table 5). In the non-intervened, no significant increase in albumin levels was seen.

\subsubsection{Electrolytes and Trace Elements}

Among electrolytes and trace elements, the most significant increase was seen in Mg in the intervened, while the change in Mg in the non-intervened was much lower (Table 4 and Table 5).

\subsection{Geriatric Nutritional Risk Index (GNRI)}

To classify the nutritional risk, GNRI was employed. In the intervened, GNRI improved from $88.7 \pm 6.3$ to 95.7 \pm 4.5 in the intervened; at the start of intervention, it was classified as intermediate risk (GNRI $=82$ to $<92$ ) and improved to low risk (GNRI $=92$ to $\leq 98$ ) (Table 4). In the non-intervened, there was no significant change in GNRI. GNRI remained at the intermediate risk level during the trial period: $84.6 \pm 7.7$ to $86.5 \pm 7.9$ (Table 4).

\subsection{Time Course of Intervention}

The time course of intervention was analyzed regarding changes in albumin levels and GNRI at the time points of 0,4 , and 8 weeks during the intervention. Both albumin levels and GNRI significantly increased at 4 weeks, and then seemed to level off (Figure 1).

\section{Discussion}

This report describes a nutritional intervention study of the elderly living in nursing homes in Shanghai by employing a balanced liquid nutrition formula containing casein as a major protein source (90\% of total protein). The elderly who participated in this study were suffering from hypoalbuminemia or protein-malnutrition as assessed by an albumin level below $35 \mathrm{~g} / \mathrm{L}$. During the intervention period, liquid formulas were added to their daily diets. By this intervention, their albumin levels recovered to well above $35 \mathrm{~g} / \mathrm{L}$, and nutritional risk levels improved as well. 
Table 4. Physical and biochemical measures.

\begin{tabular}{|c|c|c|c|c|c|c|c|c|}
\hline & \multirow{2}{*}{ Unit } & \multicolumn{2}{|c|}{ Intervened } & \multirow{2}{*}{$\mathrm{p}$} & \multicolumn{2}{|c|}{ Non-intervened } & \multirow{2}{*}{$\mathrm{p}$} & \multirow{2}{*}{$\frac{\text { Week } 0}{p}$} \\
\hline & & Week 0 & Week 8 & & Week 0 & Week 8 & & \\
\hline Height & $\mathrm{cm}$ & $162.6 \pm 8.7$ & & & $163.9 \pm 9.3$ & & & \\
\hline Weight & $\mathrm{kg}$ & $62.8 \pm 11.1$ & $63.9 \pm 11.1$ & ${ }^{* * *}$ & $59.5 \pm 10.9$ & $59.1 \pm 10.5$ & & \\
\hline BMI & $\mathrm{kg} / \mathrm{cm}^{2}$ & $23.9 \pm 4.5$ & $24.3 \pm 4.6$ & $* * *$ & $22.0 \pm 2.6$ & $21.9 \pm 2.5$ & & \\
\hline $\mathrm{AC}$ & $\mathrm{cm}$ & $27.2 \pm 3.7$ & $28.5 \pm 3.9$ & ${ }^{* * *}$ & $24.3 \pm 4.4$ & $24.0 \pm 4.2$ & & \\
\hline TSF & $\mathrm{mm}$ & $15.6 \pm 1.4$ & $16.1 \pm 1.0$ & & $18.1 \pm 5.5$ & $17.9 \pm 5.5$ & & \\
\hline $\mathrm{AMC}$ & $\mathrm{cm}$ & $22.3 \pm 3.4$ & $23.5 \pm 3.7$ & ** & $18.6 \pm 4.1$ & $18.4 \pm 4.1$ & & \\
\hline Total protein & $\mathrm{g} / \mathrm{L}$ & $66.4 \pm 2.5$ & $66.1 \pm 3.8$ & & $63.1 \pm 4.9$ & $63.7 \pm 7.5$ & & $*$ \\
\hline Albumin & $\mathrm{g} / \mathrm{L}$ & $32.7 \pm 3.1$ & $37.3 \pm 1.9$ & $* * *$ & $30.0 \pm 4.2$ & $31.3 \pm 4.6$ & & \\
\hline Transthyretin & $\mathrm{mg} / \mathrm{L}$ & $266.5 \pm 36.1$ & $244.9 \pm 30.4$ & * & $237.8 \pm 36.1$ & $218.0 \pm 32.3$ & & * \\
\hline Transferrin & $\mathrm{g} / \mathrm{L}$ & $2.39 \pm 0.38$ & $2.26 \pm 0.51$ & & $2.02 \pm 0.64$ & $1.76 \pm 0.49$ & & \\
\hline RBP & $\mathrm{mg} / \mathrm{L}$ & $63.1 \pm 9.9$ & $62.5 \pm 13.0$ & & $58.5 \pm 9.2$ & $64.4 \pm 8.8$ & ** & \\
\hline $\mathrm{Hb}$ & $\mathrm{g} / \mathrm{L}$ & $135.0 \pm 12.2$ & $139.4 \pm 11.4$ & & $121.1 \pm 19.6$ & $119.3 \pm 19.6$ & & * \\
\hline GNRI & & $88.7 \pm 6.3$ & $95.7 \pm 4.5$ & ${ }^{* * *}$ & $84.6 \pm 7.7$ & $86.5 \pm 7.9$ & & \\
\hline Creatinine & $\mu \mathrm{mol} / \mathrm{L}$ & $70.1 \pm 16.4$ & $66.9 \pm 16.3$ & & $56.5 \pm 21.9$ & $56.5 \pm 21.4$ & & \\
\hline BUN & $\mathrm{mmol} / \mathrm{L}$ & $6.5 \pm 1.9$ & $6.3 \pm 1.4$ & & $5.7 \pm 1.6$ & $5.9 \pm 2.1$ & & \\
\hline HydPro & $\mu \mathrm{g} / \mathrm{mL}$ & $16.99 \pm 5.02$ & $14.46 \pm 1.87$ & & $18.14 \pm 3.43$ & $16.47 \pm 2.07$ & * & \\
\hline Total Chol & $\mathrm{mmol} / \mathrm{L}$ & $4.95 \pm 0.87$ & $5.23 \pm 0.86$ & & $4.51 \pm 1.04$ & $4.60 \pm 1.07$ & & \\
\hline TG & $\mathrm{mmol} / \mathrm{L}$ & $1.32 \pm 0.66$ & $1.39 \pm 0.66$ & & $1.03 \pm 0.45$ & $1.07 \pm 0.47$ & & \\
\hline APO A-I & $\mathrm{g} / \mathrm{L}$ & $1.04 \pm 0.12$ & $1.12 \pm 0.13$ & & $1.03 \pm 0.18$ & $0.99 \pm 0.17$ & & \\
\hline Leucocyte & $\times 10^{9} / \mathrm{L}$ & $5.9 \pm 1.5$ & $5.9 \pm 2.2$ & & $6.1 \pm 1.8$ & $6.8 \pm 2.1$ & & \\
\hline Erythrocyte & $\times 10^{12} / \mathrm{L}$ & $4.27 \pm 0.38$ & $4.39 \pm 0.37$ & & $3.84 \pm 0.47$ & $3.84 \pm 0.56$ & & \\
\hline $\mathrm{Na}$ & $\mathrm{mmol} / \mathrm{L}$ & $140.5 \pm 4.3$ & $138.3 \pm 2.3$ & $* *$ & $140.1 \pm 2.3$ & $139.3 \pm 2.3$ & & \\
\hline $\mathrm{K}$ & $\mathrm{mmol} / \mathrm{L}$ & $4.1 \pm 0.3$ & $4.2 \pm 0.3$ & & $4.0 \pm 0.6$ & $4.1 \pm 0.6$ & & \\
\hline $\mathrm{Cl}$ & $\mathrm{mmol} / \mathrm{L}$ & $104.3 \pm 2.2$ & $103.2 \pm 2.3$ & & $101.8 \pm 4.6$ & $105.0 \pm 4.0$ & * & \\
\hline $\mathrm{Ca}$ & $\mathrm{mmol} / \mathrm{L}$ & $2.19 \pm 0.10$ & $2.24 \pm 0.11$ & * & $2.15 \pm 0.07$ & $2.17 \pm 0.10$ & & \\
\hline $\mathrm{Mg}$ & $\mathrm{mmol} / \mathrm{L}$ & $23.3 \pm 1.3$ & $36.9 \pm 3.3$ & ${ }^{* * *}$ & $23.6 \pm 1.4$ & $25.3 \pm 6.6$ & & \\
\hline $\mathrm{P}$ & $\mathrm{mmol} / \mathrm{L}$ & $1.16 \pm 0.22$ & $1.12 \pm 0.16$ & & $1.21 \pm 0.14$ & $1.19 \pm 0.13$ & & \\
\hline $\mathrm{Cu}$ & $\mu \mathrm{g} / \mathrm{L}$ & $949.3 \pm 180.8$ & $1136.5 \pm 415.0$ & & $957.3 \pm 211.0$ & $1059.6 \pm 218.9$ & & \\
\hline $\mathrm{Zn}$ & $\mu \mathrm{g} / \mathrm{L}$ & $928.5 \pm 145.8$ & $1024.5 \pm 109.6$ & $*$ & $801.7 \pm 132.8$ & $849.5 \pm 117.7$ & & $*$ \\
\hline Se & $\mu \mathrm{g} / \mathrm{L}$ & $132.0 \pm 20.4$ & $117.9 \pm 8.3$ & $* *$ & $112.4 \pm 6.6$ & $112.3 \pm 3.3$ & & ** \\
\hline
\end{tabular}

Data are shown as average \pm standard deviation. Comparisons were made between the start and end point of the trial in each group, and between the two groups at the start of trial. Statistical significance is shown by asterisks: ${ }^{*} p<0.05 ;{ }^{* *} p<0.01 ;{ }^{* * * *} p<0.001$. Normal ranges: Total protein, $65-85$ g/L; Albumin, 35 - 55 g/L; Transthyretin, 200 - 400 mg/L; Transferrin, 2.4 - 4.0 g/L; RBP, 25 - 70 mg/L; Hb, 110 - 165 g/L; Creatinine, 30 - 120 $\mu \mathrm{mol} / \mathrm{L}$; BUN, 2.4 - $7.1 \mathrm{mmol} / \mathrm{L}$; Total Chol, 3.1 - $5.7 \mathrm{mmol} / \mathrm{L} ; \mathrm{TG}, 0.6$ - $1.7 \mathrm{mmol} / \mathrm{L} ;$ APO A-I, 0.9 - 1.76 g/L; Leucocyte, 4 - $10 \times 10^{9} / \mathrm{L}$; Erythrocyte, 3.5 - $5.5 \times 10^{12} / \mathrm{L} ; \mathrm{Na}, 135$ - $147 \mathrm{mmol} / \mathrm{L} ; \mathrm{K}, 3.6$ - $5.1 \mathrm{mmol} / \mathrm{L} ; \mathrm{Cl}, 96$ - $10^{8} \mathrm{mmol} / \mathrm{L} ; \mathrm{Ca}, 2.1$ - $2.8 \mathrm{mmol} / \mathrm{L} ; \mathrm{Mg}, 20$ - $40 \mathrm{mmol} / \mathrm{L} ; \mathrm{P}, 0.81$ - 1.6 $\mathrm{mmol} / \mathrm{L} ; \mathrm{Cu}, 750$ - $1800 \mu \mathrm{g} / \mathrm{L} ; \mathrm{Zn}, 720-1800 \mu \mathrm{g} / \mathrm{L} ; \mathrm{Se}, 103-190 \mu \mathrm{g} / \mathrm{L}$. 
Table 5. Changes from start to end measures.

\begin{tabular}{|c|c|c|c|}
\hline & Intervened & Non-intervened & $\mathrm{p}$ \\
\hline Weight & $1.1 \pm 1.0$ & $-0.4 \pm 1.1$ & $* * *$ \\
\hline BMI & $0.4 \pm 0.4$ & $-0.1 \pm 0.4$ & $* * *$ \\
\hline $\mathrm{AC}$ & $1.4 \pm 1.2$ & $-0.3 \pm 0.8$ & $* * *$ \\
\hline ATS & $0.4 \pm 1.2$ & $-0.2 \pm 0.5$ & \\
\hline AMC & $1.2 \pm 1.4$ & $-0.2 \pm 0.8$ & ** \\
\hline Total protein & $-0.3 \pm 2.6$ & $0.5 \pm 7.9$ & \\
\hline Albumin & $4.5 \pm 2.1$ & $1.3 \pm 4.8$ & * \\
\hline Transthyretin & $-21.5 \pm 38.3$ & $-19.8 \pm 40.2$ & \\
\hline Transferrin & $-0.13 \pm 0.60$ & $-0.25 \pm 0.83$ & \\
\hline RBP & $-0.6 \pm 18.8$ & $5.9 \pm 6.1$ & \\
\hline $\mathrm{Hb}$ & $4.4 \pm 14.1$ & $-1.7 \pm 15.0$ & \\
\hline GNRI & $7.0 \pm 3.3$ & $3.5 \pm 8.2$ & * \\
\hline Creatinine & $-3.2 \pm 6.7$ & $-0.1 \pm 25.7$ & \\
\hline BUN & $-0.2 \pm 2.9$ & $0.1 \pm 1.1$ & \\
\hline HydPro & $-2.53 \pm 5.44$ & $-1.68 \pm 2.67$ & \\
\hline Total Chol & $0.29 \pm 1.04$ & $0.09 \pm 0.60$ & \\
\hline TG & $0.07 \pm 0.71$ & $0.04 \pm 0.29$ & \\
\hline APO A-I & $0.08 \pm 0.16$ & $-0.04 \pm 0.16$ & * \\
\hline Leucocyte & $0.08 \pm 1.86$ & $0.68 \pm 2.18$ & \\
\hline Erythrocyte & $0.12 \pm 0.36$ & $0.00 \pm 0.43$ & \\
\hline $\mathrm{Na}$ & $-2.2 \pm 2.7$ & $-0.9 \pm 2.4$ & \\
\hline K & $0.2 \pm 0.5$ & $0.1 \pm 0.5$ & \\
\hline $\mathrm{Cl}$ & $-1.1 \pm 2.8$ & $3.2 \pm 5.2$ & ** \\
\hline $\mathrm{Ca}$ & $0.05 \pm 0.08$ & $0.02 \pm 0.08$ & \\
\hline $\mathrm{Mg}$ & $13.6 \pm 4.0$ & $1.7 \pm 6.0$ & *** \\
\hline $\mathrm{P}$ & $-0.05 \pm 0.17$ & $-0.03 \pm 0.15$ & \\
\hline $\mathrm{Cu}$ & $187.3 \pm 403.8$ & $102.3 \pm 190.3$ & \\
\hline $\mathrm{Zn}$ & $96.1 \pm 167.6$ & $47.9 \pm 171.7$ & \\
\hline Se & $-14.1 \pm 16.2$ & $-0.1 \pm 6.3$ & ** \\
\hline
\end{tabular}

Data are shown as average \pm standard deviation. Statistical significance is shown by asterisks: ${ }^{*} \mathrm{p}<0.05 ;{ }^{* *} \mathrm{p}<0.01 ;{ }^{* * *} \mathrm{p}<0.001$. 


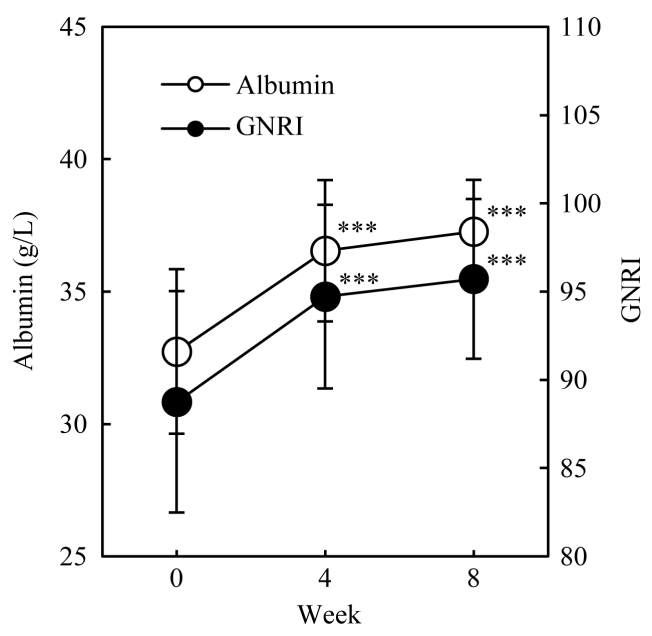

Figure 1. Time course of albumin levels and GNRI during intervention. Albumin levels and GNRI assessed at the indicated time points during intervention are shown. Asterisks indicate statistical significance: ${ }^{* * *} \mathrm{p}<0.001$.

\subsection{Dietary Intake}

Basal energy expenditures of the elderly who participated in this study were calculated to be $1267 \pm 150 \mathrm{kcal}$ for the intervened and $1242 \pm 172 \mathrm{kcal}$ for the non-intervened, according to the Harris-Benedict equation [17]. When the activity factor of 1.3 is applied, assuming that the participants' daily activities are between sedentary and lightly active, their daily energy needs are calculated to be $1648 \pm 195 \mathrm{kcal}$ for the intervened and $1615 \pm$ $224 \mathrm{kcal}$ for the non-intervened. These figures coincide with those of the daily energy intakes of the intervened, $1738 \pm 240 \mathrm{kcal}$, and the non-intervened, $1612 \pm 187 \mathrm{kcal}$. These estimates indicate that the daily energy intakes of the participants were at an adequate level. This assumption is confirmed by the fact that their BMIs ranged from 22 to 24, an appropriate level.

Meanwhile, the fact that the daily energy intakes of the intervened and non-intervened were at similar levels suggests that the improvement of albumin levels was not due to an increase in energy intake but rather should be attributable to an increase in protein intake. On the basis of the energy intake and its PFC ratio, the actual amount of protein intake is estimated to have been $71.2 \mathrm{~g} /$ day in the intervened and $52.5 \mathrm{~g} /$ day in the non-intervened. Assuming that the recommended dietary allowance (RDA) of protein for the elderly is 1.0 to 1.2 $\mathrm{g} / \mathrm{kg} /$ day [18], daily protein requirements are calculated to be 62.8 to $76.7 \mathrm{~g} /$ day for the elderly in the intervened and 59.5 to $70.9 \mathrm{~g} /$ day in the non-intervened. The actual intake levels of protein in the intervened accord well with the estimated range of protein RDA; it is reasonable to consider that the increase in albumin levels in the intervened was due to an increase in intake levels of protein as a result of the intervention.

\subsection{Level of Intervention}

In this study, a formula with $400 \mathrm{kcal} /$ day of energy was included in the daily diet. As a result of this level of intervention, changes were seen in protein-related markers as above. It is not currently clear if this level of intervention is the most appropriate. The time period of intervention in this study was 8 weeks. When the measures at 0,4 , and 8 weeks of intervention were compared, albumin levels as well as GNRI significantly increased and seemed to level off at 4 weeks. This suggests that an intervention period of 4 weeks might be long enough; however, it also suggests that an intervention period longer than 4 weeks might be required to reach a stable level of nutrition.

A characteristic feature of the intervention in this study is that intakes of the formulas took place between daily meals. This style of formula administration might have been effective in providing protein sources to maintain better anabolic metabolism of protein. When protein supplementation was considered in terms of protein synthesis in the body, a large bolus intake at onetime is not recommended; rather intake evenly distributed 
throughout the day is better to retain a high level of protein synthesis in the body [19]. The formula placements in this study agree with this recommendation. It can be speculated that the nutritionally balanced formulas provided a wide range of nutrition including protein throughout the day, resulting in a better time distribution of nutritional provision to retain a reasonable level of metabolism, including protein anabolism.

\subsection{Electrolytes and Trace Elements}

The levels of electrolytes and trace elements in the participants were within normal ranges throughout the trial period, irrespective of whether they were intervened or non-intervened. However, a significant increase in $\mathrm{Mg}$ levels was observed. $\mathrm{Mg}$ is known as an electrolyte that enhances protein synthesis in cultured cells [20]-[22]; therefore, an increase in Mg levels might be related to enhanced protein metabolism in the intervened. The level of $\mathrm{Mg}$ might have necessarily increased as it was supplied from a reservoir to coordinate the increase in protein metabolism. It is not clear if the increase in Mg levels was due to its supply from the formula.

$\mathrm{Zn}$ is also known to be related to enhancement of protein synthesis, such that $\mathrm{Zn}$ finger proteins are involved as the machinery of protein synthesis systems [22] [23]. An increase in Zn levels might be discussed in the same manner as an increase in $\mathrm{Mg}$ levels.

\subsection{Nutritional Risk}

It is known that PEM is strongly related to an increased risk of mortality, since malnutrition increases the incidence of a variety of diseases including infectious diseases [24]-[27]. It is also known that PEM augments physical functions of the elderly and aggravates physical dysfunction [27] [28]. Geriatric nutritional risk index (GNRI) was proposed to identify or classify mortality/morbidity risk levels in relation to PEM levels, which are defined by albumin levels and body weight; GNRI is calculated by an equation using albumin levels and body weight as variables. However, it is also designed to be applicable to subjects whose weight loss is not significant. Therefore, GNRI was applied to classify levels of nutritional risk of the elderly in this study.

The intervened in this study were classified as being at the intermediate risk level of GNRI at the start of the trial, and they then recovered to the level of low risk after intervention. This result indicates that the intervention using the formula was effective to help the elderly improve their albumin levels. In other words, the elderly need to modify their daily diets by some means; if they do not improve their diets, they may lose weight as aging proceeds, and they may eventually suffer from PEM, resulting in increased levels of nutritional risk.

\subsection{Long-Term Intake of Casein as a Major Protein Source}

The balanced liquid formula used in this study contains cow milk casein as a major protein source (90\%). Casein is a class of protein in milk that is recognized as a slowly available protein; casein curds in the stomach and is slowly excreted into the jejunum. Due to this slow gastric emptying, casein shows different characteristics with respect to postprandial blood amino acid levels as compared with other proteins such as whey proteins that do not curd; whey proteins increase postprandial blood amino acid levels more than casein does [29]. Based on these results, it is suggested that greater levels of transient blood amino acid induced by whey proteins might compensate for impaired sensitivity to blood amino acids in the elderly, and improve their protein-malnutrition [30]. In contrast to these speculations, the balanced liquid formula containing casein as a major protein source was shown to improve protein-malnutrition in the elderly as described in this report. Our results suggest that long term intake of protein (either whey, casein or a mixture) is necessary to improve protein-malnutrition and maintain body protein balance.

\subsection{Merits of Using Balanced Liquid Nutrition Formula}

There are two major ways to improve daily diet intakes; one is to modify daily diets themselves, and the other is to apply nutritional support. Modification of daily diets so as to meet daily dietary needs is probably the better way than mundanely applying nutritional supports. However, a trial to modify diets faces the difficulties that it requires subjects to overcome lifestyle habits and it takes time to obtain nutritional knowledge and then apply it to one's daily diet. Even though the ideal goal may be the long-lasting modification of daily diet, nutritional support will provide a beneficial means to supply nutritionally high-quality diets to help fulfill daily requirements without deteriorating the nutritional balance of daily diets. The formulas would be usable as a means to 
improve the nutritional status of the elderly when appropriately applied in nutritional improvement programs.

\section{References}

[1] Incalzi, R.A., Gemma, A., Capparella, O., Cipriani, L., Landi, F. and Carbonin, P. (1996) Energy Intake and In-Hospital Starvation. A Clinically Relevant Relationship. Archives of Internal Medicine, 156, 425-429. http://dx.doi.org/10.1001/archinte.1996.00440040101011

[2] AntonelliIncalzi, R., Landi, F., Cipriani, L., Bruno, E., Pagano, F., Gemma, A., Capparella, O. and Carbonin, P.U. (1996) Nutritional Assessment: A Primary Component of Multidimensional Geriatric Assessment in the Acute Care Setting. Journal of the American Geriatrics Society, 44, 166-174.

[3] Landi, F., Zuccala, G., Gambassi, G., Incalzi, R.A., Manigrasso, L., Pagano, F., Carbonin, P. and Bernabei, R. (1999) Body Mass Index and Mortality among Older People Living in the Community. Journal of the American Geriatrics Society, 47, 1072-1076.

[4] Cederholm, T., Jagren, C. and Hellstrom, K. (1995) Outcome of Protein-Energy Malnutrition in Elderly Medical Patients. American Journal of Medicine, 98, 67-74. http://dx.doi.org/10.1016/S0002-9343(99)80082-5

[5] Gavazzi, G. and Krause, K.-H. (2002) Ageing and Infection. Lancet Infect Disease, 2, 659-666. http://dx.doi.org/10.1016/S1473-3099(02)00437-1

[6] Sugiyama, M., Shimizu, R., Wakagi, Y., Nakamoto, N., Koyama, W., Mihashi, F. and Koyama, H. (2000) Protein Energy Malnutrition inthe Elderly (in Japanese). Eiyo-Hyouka-to-Chiryou (Nutrition Assessment and Practice), 17, 553-562.

[7] Cederholm, T. and Hellstrom, K. (1992) Nutritional Status in Recently Hospitalized and Free-Living Elderly Subjects. Gerontology, 38, 105-110. http://dx.doi.org/10.1159/000213314

[8] MacWhirter, J.P. and Pennington, C.R. (1994) Incidence and Recognition of Malnutrition in Hospital. British Medical Journal, 308, 945- 948. http://dx.doi.org/10.1136/bmj.308.6934.945

[9] Elmstahl, S., Persson, M., Andren, M. and Blabolil, V. (1997) Malnutrition in Geriatric Patients: A Neglected Problem?” Journal of Advanced Nursing, 26, 851-855. http://dx.doi.org/10.1046/j.1365-2648.1997.00404.x

[10] Tomaiolo, P.P., Enman, S. and Kraus, V. (1981) Preventing and Treating Malnutrition in the Elderly. Journal of Parenteral and Enteral Nutrition, 5, 46-48. http://dx.doi.org/10.1177/014860718100500146

[11] Lipshitz, D.A., Mitchell, C.O., Steele, R.W. and Milton, K.Y. (1985) Nutritional Evaluation and Supplementation of Elderly Subjects Participating in a "Meals on Wheels" Program. Journal of Parenteral and Enteral Nutrition, 9, 343347. http://dx.doi.org/10.1177/0148607185009003343

[12] Mitchell, S.L., Kiely, D.K. and Lipsitz, L.A. (1997) The Risk Factors and Impact on Survival of Feeding Tube Placement in Nursing Home Residents with Severe Cognitive Impairment. Archives of Internal Medicine, 157, 327-332. http://dx.doi.org/10.1001/archinte.1997.00440240091014

[13] Gomez, F., Galvan, R.R., Cravioto, J. and Frenk, S. (1955) Malnutrition in Infancy and Childhood with Special Reference to Kwashiorkor. Advances in Pediatrics, 7, 131-169.

[14] Waterlow, J.C. (1972) Classification and Definition of Protein-Calorie Malnutrition. British Medical Journal, 3, 566569. http://dx.doi.org/10.1136/bmj.3.5826.566

[15] Gitlin, D., Cravioto, J., Frenk, S., Montano, E.L., Galvan, R.R., Gomez, F. and Janeway, C.A. (1958) Albumin Metabolism in Children with Protein Malnutrition. Journal of Clinical Investigation, 37, 682-686. http://dx.doi.org/10.1172/JCI103654

[16] Bouillanne, O., Morineau, G., Dupont, C., Coulombel, I., Vincent, J.P., Nicolis, I., Benazeth, S., Cynober, L. and Ausse, C. (2005) Geriatric Nutritional Risk Index: A New Index for Evaluating At-Risk Elderly Medical Patients. American Journal of Clinical Nutrition, 82, 777-783.

[17] Harris, J.A. and Benedict, F.G. (1918) ABiometric Study of Human Basal Metabolism. Proceedings of the National Academy of Sciences of the USA, 4, 370-373. http://dx.doi.org/10.1073/pnas.4.12.370

[18] Gaffney-Stomberg, E., Insogna, K.L., Rodriguez, N.R. and Kerstetter, J.E. (2009) Increasing Dietary Protein Requirements in Elderly People for Optimal Muscle and Bone Health. Journal of the American Geriatrics Society, 57, 10731079. http://dx.doi.org/10.1111/j.1532-5415.2009.02285.x

[19] Paddon-Jones, D. and Rasmussen, B.B. (2009) Dietary Protein Recommendations and the Prevention of Sarcopenia: Protein, Amino Acid Metabolism and Therapy. Current Opinion in Clinical Nutrition and Metabolic Care, 12, 86-90. http://dx.doi.org/10.1097/MCO.0b013e32831cef8b

[20] Rubin, H. (1975) Central Role for Magnesium in Coordinate Control of Metabolism and Growth in Animal Cells. Proceedings of the National Academy of Sciences of the USA, 72, 3551-3555. http://dx.doi.org/10.1073/pnas.72.9.3551

[21] Terasaki, M. and Ribin, H. (1985) Evidence That Intracellular Magnesium Is Present in Cells at a Regulatory Concen- 
tration for Protein Synthesis. Proceedings of the National Academy of Sciences of the USA, 82, 7324-7326. http://dx.doi.org/10.1073/pnas.82.21.7324

[22] Dørup, I. and Clausen, T. (1991) Effects of Magnesium and Zinc Deficiencies on Growth and Protein Synthesis in Skeletal Muscle andthe Heart. British Journal of Nutrition, 66, 493-504. http://dx.doi.org/10.1079/BJN19910050

[23] Savarino, L., Granchi, D., Ciapetti, G., Cenni, E., Ravaglia, G., Forti, P., Maioli, F. and Mattioli, R. (2001) Serum Concentrations of Zinc and Selenium in Elderly People: Results in Healthy Nonagenarians/Centenarians. Experimental Gerontology, 36, 327-339. http://dx.doi.org/10.1016/S0531-5565(00)00218-7

[24] Kuller, L.H., Eichner, J.E. and Orcahrd, T.J. (1991) The Relationship Between Serum Albumin Levels and Risk of Coronary Heart Disease in the Multiple Risk Factor Intervention Trial. American Journal of Epidemiology, 134, 12661277.

[25] Klonoff-Cohen, H., Barrett-Conor, E.L. and Edelstein, S.L. (1992) Albumin Level as a Predictor of Mortality in the Healthy Elderly. Journal of Clinical Epidemiology, 45, 207-212. http://dx.doi.org/10.1016/0895-4356(92)90080-7

[26] Gillum, R.F., Ingram, D.D. and Makuc, D.M. (1994) Relationship between Serum Albumin Concentration and Stroke Incidence and Death: The HHANES I, Epidemiologic Follow-Up Study. American Journal of Epidemiology, 140, 876888.

[27] Gottschlich, M.M., Matarese, L.E. and Shronts, E. (1993) Nutrition Support Dietetics Core Curriculum. 2nd Edition, Silver Spring, Aspen.

[28] Corti, M.C., Guralnik, J.M., Salive, M.E. and Sorkin, J.D. (1994) Serum Albumin Level and Physical Disability as Predictors of Mortality in Older Persons. Journal of the American Medical Association, 272, 1036-1042. http://dx.doi.org/10.1001/jama.1994.03520130074036

[29] Boirie, Y., Dangin, M., Gachon, P., Vasson, M.P., Maubois, J.L. and Beaufrère, B. (1997) Slow and Fast Dietary Proteins Differently Modulate Postprandial Protein Accretion. Proceedings of the National Academy of Sciences of the USA, 94, 14930-14935. http://dx.doi.org/10.1073/pnas.94.26.14930

[30] Dangin, M., Guillet, C., Garcia-Rodenas, C., Gachon, P., Bouteloup-Demange, C., Reiffers-Magnani, K., Fauquant, J., Ballèvre, O. and Beaufrère, B. (2003) The Rate of Protein Digestion Affects Protein Gain Differently during Aging in Humans. Journal of Physiology, 549, 635-644. http://dx.doi.org/10.1113/jphysiol.2002.036897 